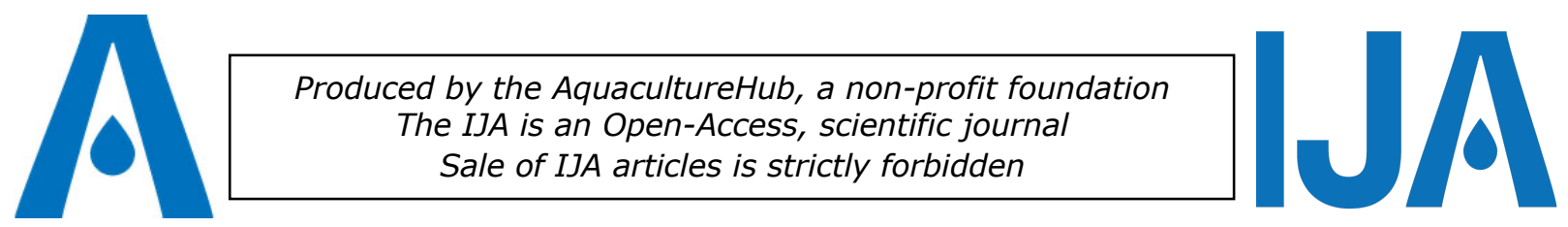

\title{
Potential role of L-ascorbic acid with Field cricket (Gryllus bimaculatus) meal in diets of Nile Tilapia (Oreochromis niloticus) during sex reversal and nursing
}

\author{
Anusha Dilhani Perera1*, Ram C. Bhujel ${ }^{1}$
}

\author{
${ }^{1}$ Aquaculture and Aquatic Resources Management (AARM) \\ School of Environment, Resources and Development (SERD) \\ Asian Institute of Technology (AIT), Klong Luang, Pathum Thani 12120, Thailand
}

Key words: L-ascorbic acid, Nile tilapia, Sex-reversal, Nursing, Field cricket meal, Gonad histology, growth and survival

\begin{abstract}
A synthetic androgen 17-a methyl testosterone (MT) commonly used in the production of mono-sex fry of Nile tilapia (Oreochromis niloticus) during the first 21 days for sex reversal has been considered to suppress immunity thereby reduce survival. Present trial was conducted to evaluate whether vitamin C ( $L$ ascorbic acid, AA) supplementation would benefit in terms of survival, growth, and stress resistance. Nile tilapia fry were fed with isonitrogenous $(57.8 \pm 0.2 \%$ $\mathrm{CP}$ ) diets formulated using Field cricket (Gryllus bimaculatus) meal (approx. $79 \%$ ) and fish meal (approx. 20\%) to use as control, and five other diets were prepared by supplementing 10, 20, 3040 and $50 \mathrm{~g}$ of vitamin C (L-ascorbic acid per $\mathrm{kg}$ diet). Eighteen aquaria or glass tanks $(100 \mathrm{~L})$ were used having three replicates per treatment. Each aquarium was stocked with 300 fish $(0.01 \pm 0.00$ g). Fry were nursed for another 91 days to check their sex-ratio. Gonad histology showed increased number of spermatogonia when L-ascorbic dose was $30 \mathrm{~g} / \mathrm{kg}$ diet. At the end of the feeding trial results indicated significant increase $(P<0.05)$ in growth, feed utilization and survival when fed with vitamin $C$ at the dose of 10 $\mathrm{g} / \mathrm{kg}$ diet during sex-reversal and nursing periods as compared to the control. Similarly, hematological information also showed $10 \mathrm{~g}$ vitamin $\mathrm{C}$ dose per $\mathrm{kg}$ diet. Polynomial regression showed that the optimum dietary ascorbic acid doses were calculated at $15.9,10.0$ and $12.0 \mathrm{~g} \mathrm{AA}$ per $\mathrm{kg}$ diet for highest survival $(83.5 \%$ max), weight gain and SGR, respectively, but the doses higher than $20 \mathrm{~g}$ of Lascorbic acid/kg diet was not beneficial. Highest apparent digestibility (AD\%) of protein $(84.1 \%)$ was at $15.37 \mathrm{~g}$ and $A D \%$ of lipid (91.4\% max) was $17.8 \mathrm{~g}$ of vitamin $\mathrm{C} / \mathrm{kg}$ diet. Salinity challenge test also showed highest survival can be achieved at $15.8 \mathrm{~g} \mathrm{AA}$ per $\mathrm{kg}$ diet. As the survival of fry is the most important parameter at these stages, the dose which resulted highest survival i.e., $15 \mathrm{~g} / \mathrm{kg}$ diet is recommended.
\end{abstract}

\footnotetext{
* Corresponding author. Tel.: +66900986147, e-mail: anu.perera22@gmail.com
} 


\section{Introduction}

All-male tilapia farming rapidly expanded worldwide as profitable business due to its high growth, hardiness, and human nutritional benefits which contributes food and nutrition security globally (Bhujel, 2014). Fishmeal (FM) is used as the main protein source and 60 mg 17-a methyl-testosterone steroid (MT) hormone used per $\mathrm{kg}$ feed for sex reversal to feed for 21 days (Little et al., 2003; Bhujel, 2009, 2014), and $10 \mathrm{mg}$ MT per kg feed (Ron et al., 1995). Due to sustainability issue of fishmeal, its use in aquaculture has been questioned and various attempts have been made to reduce or replace it completely. Fishmeal is used as sole ingredient of the standard feed for hormonal sex-reversal in tilapia. Therefore, nowadays, insect meals are getting attraction amongst researchers and feed producers due to their potential as fishmeal replacement (FAO, 2013).

Field cricket meal (FCM) is a good source of protein, amino acid, lipids (Wang et al., 2005), minerals ( $\mathrm{Na}, \mathrm{K}, \mathrm{P}$ and $\mathrm{Zn}$ ) and vitamins (B1, B12, E, K) (Khan, 2018). An earlier report has showed that Field cricket successfully replaced soya bean in broiler diet (Wang et al., 2005) and suitable source for alternative protein resources for fish diet. FCM could replace up to $100 \%$ of fishmeal in Clarias gariepinus (Taufek et al., 2016a; 2017). Field cricket can be found in abundance in the tropics and locally available in Thailand (Van Huis et al., 2013). They can be easily cultured, and mass harvested in controlled environments with the benefit of low cost of production. However, there is no good alternative found so far to replace fishmeal partially or fully for Nile tilapia swim-up fry during sex reversal. Some literature has indicated the immunity problem might be due to the side effect of MT steroid hormone causing histopathological changes on gill, liver, kidneys, and intestine (Abo-Al-Ela, 2018; Suseno et al., 2020). Due to poor immunity, fish may get negative effects during overcrowding, periodic handling, sudden rise and fall in temperature, poor water quality and poor nutritional status leading to stress or immunosuppressant causing increased susceptibility to diseases (Bhujel, 2014). However, both fish meal and FCM are deficient in vitamin $C$. In an earlier report it has been suggested that males showed lower lysozyme activity than females (Saha et al., 2010); therefore, attention has been given on sex reversal tilapia feed. Initial feeding of early life stages is more sensitive to vitamin C deficiency (Dabrowski et al., 1996) as they grow faster than adults (Kolkovski et al., 2000).

Vitamin C or L-Ascorbic acid is water soluble health-promoting agent in aquaculture (Eo and Lee, 2008). However, fish cannot synthesize vitamin C (ascorbic acid, AA) in their body due to lack of L-gulonolactone oxidase enzyme (Eo and Lee, 2008). Therefore, an exogenous source of vitamin C is very essential in fish diets (Wang et al. 2003). Early larvae stage feeding with vitamin $\mathrm{C}$ reduces fish stress and antioxidation status (JiménezFernández et al., 2015). An earlier report has showed that vitamin $\mathrm{C}$ regulates the immunetoxic effect such as higher phagocytic activity, phagocytic index and lysozyme activity of MT in tilapia fry and that help to increase fish survival (Abo-Al-Ela et al., 2017). In addition, vitamin $C$ helps to minimize toxicity by water contaminants (Eo and Lee, 2008), survival and disease resistant (Suwanmanee et al., 2012). Shahkar et al. (2015) reported that changes of testes colour and proliferation of spermatogonia while increasing ascorbic acid dose in brood stock Japanese eel. However, there was no publication on tilapia fry testes. Inadequate supply of ascorbic acid causes poor growth, poor immunity, higher mortality, poor muscle quality, and impaired collagen formation (Shahkar et al., 2015; Wei et al., 2020). On the other hand, higher dose of vitamin C showed spinal deformities for channel catfish (Naggar and Lovell, 1991) and limited reported on higher dose effects on fish. Therefore, Vitamin $\mathrm{C}$ is essential nutrient for all the cultured fish species including tilapia (Toyama et al., 2000; Nsonga et al., 2010; Saha et al., 2010; Suwanmanee et al., 2012; Martins et al., 2016; Vieira et al., 2018). Quantitative requirements of vitamin C depends on the fish species, age, size, stages of development, and culture conditions (Nsonga et al., 2010). 
Publications are limited regarding the benefits of vitamin C for SRT and nursing fry (Toyama et al., 2000; Suwanmanee et al., 2012). Although, there were no reports on vitamin $C$ dose used for supplementation above $5 \mathrm{~g} \mathrm{AA} / \mathrm{kg}$ diet used for sex reversal treatment and the effect on testes, $10 \mathrm{~g} / \mathrm{kg}$ was recommended based on the existing practice. Fry often die at high rate during sex reversal putting challenges in terms of survival due to compromised immunity caused by steroid hormone i.e., MT. These indicated that some research on vitamin $\mathrm{C}$ has been done for standard feeding protocol; however, research is limited when inclusion of FCM as the main source of protein instead of commonly used fishmeal. Present study uses the FCM replacing almost $80 \%$ of the fish meal as per our earlier outcome of trial. However, whether it had any impact on immunity was not known. Therefore, present experiment was conducted to assess the effects of vitamin $\mathrm{C}$ which is considered to play a role on the survival, growth, feed utilization and immunity / stress resistance of Nile tilapia fry.

\section{Experimental fish and system}

\section{Materials and Methods}

An experiment was conducted at the Aquaculture laboratory facility of the Asian Institute of Technology (AIT) $\left(14.1^{\circ} \mathrm{N}\right.$ and $\left.100.6^{\circ} \mathrm{E}\right)$, Thailand using the standard protocol of hormonal treatment of 21 days followed by nursing for 91 days i.e., a total of 112 days during March-June 2020. Free swimming fry of Nile tilapia (Oreochromis niloticus) were collected from the Department of Fisheries (DOF), Pathum Thani province in central Thailand. Initial fry were sampled for proximate analysis. Swim-up fry $(0.01 \pm 0.00 \mathrm{~g}$, mean $\pm \mathrm{SE}$, ) were transferred randomly distributed to 18 glass tanks (300 fish/tank, 6 treatment with three replicates) with $100 \mathrm{~L}$ volume of dechlorinated freshwater. During the experiment, compressed air diffused was supplied in each glass tank through air-stones to ensure dissolved oxygen (DO) remains adequately high. During hormonal treatment, the fry were fed with test-diets five times per day for 21 days. They were further nursed for 91 days feeding with the diets which contained the same ratio of FM and FCM but with the addition of rice bran and other ingredients. At the beginning, the individual weight and length of each fish was recorded, then the fish from each replicate tank were weighed in batches. Three fish were sampled: one per replicate, for each treatment. They were pooled and stored in a freezer $\left(-20^{\circ} \mathrm{C}\right)$ for proximate analysis. Fish mortality and feed intakes were recorded daily during the experimental period. Settle fish waste and uneaten feed were siphoned daily and water volume was kept same level for each tank. The proximate composition (AOAC, 2003) and amino acid profile (In-house method WI-TMC-06) of fishmeal (FM) and FCM are shown in Table 1. 
Table 1 Proximate composition and amino acid profile of Fishmeal and FCM compared to dietary amino acid requirements of Oreochromis niloticus.

\begin{tabular}{lrrr}
\hline Components & Fishmeal & $F C M$ & $\begin{array}{r}\text { Dietary } \\
\text { requirements }\end{array}$ \\
\hline Dry matter (\%) & $89.2^{\mathrm{a}} \pm 0.0$ & $91.6^{\mathrm{b}} \pm 0.1$ & - \\
Protein (\%) & $56.0^{\mathrm{a}} \pm 0.2$ & $56.6^{\mathrm{a}} \pm 0.2$ & $40-45$ \\
Lipid (\%) & $10.0^{\mathrm{a}} \pm 0.3$ & $23.4^{\mathrm{b}} \pm 0.5$ & -15 \\
Fiber (\%) & $1.1^{\mathrm{a}} \pm 0.1$ & $7.0^{\mathrm{b}} \pm 0.1$ & - \\
Ash (\%) & $22.5^{\mathrm{a}} \pm 0.2$ & $11.6^{\mathrm{b}} \pm 0.2$ & - \\
$\mathrm{GE}^{1}(\mathrm{kcal} / \mathrm{kg})$ & $4533^{\mathrm{a}} \pm 19$ & $5475^{\mathrm{b}} \pm 33$ & 2.82 \\
\hline Amino acid profile & & & 1.05 \\
Arginine & 3.96 & 4.29 & 2.01 \\
Histidine & 5.98 & 4.51 & 3.40 \\
Isoleucine & 2.61 & 2.37 & 3.78 \\
Leucine & 3.96 & 3.55 & 0.99 \\
Lysine & 5.45 & 3.57 & 2.50 \\
Methionine & 1.94 & 1.45 & 0.43 \\
Phenylalanine & 3.64 & 4.17 & \\
Threonine & 4.19 & 3.47 & \\
Tryptophan & 3.33 & 2.86 & \\
Tyrosine & 1.86 & 2.48 & \\
Alanine & 4.07 & 3.26 & \\
Aspartic acid & 5.22 & 4.14 & \\
Cystine & 1.52 & \\
Glutamic acid & 1.33 & 5.28 & \\
Glycine & 7.09 & 2.92 & \\
Proline & 4.13 & 1.58 & \\
Serine & 2.04 & 2.64 & \\
Valine & 2.58 & 2.63 & \\
\hline
\end{tabular}

All values are Mean $\pm \mathrm{SE}$, calculate from three replicates. $\mathrm{SE}=$ Standard error.

${ }^{1}$ Gross energy (GE) was calculated according to NRC (1993) as 5.65, 9.45, and $4.11 \mathrm{kcal} / \mathrm{g}$ for protein, lipid, and carbohydrate, respectively.

${ }^{2}$ Dietary requirements of Oreochromis niloticus; Essential amino acid (Santiago and Lovell, 1988); Protein (El-

Sayed and Teshima, 1992); Fat (Ng and Chong, 2004)

\section{Experimental diet and design}

Adult live Field crickets were collected from Talat Thai market located in Klong Luang, Pathum Thani approx. $42 \mathrm{~km}$ north of Bangkok where these Field crickets are sold as human food. They were dried in an oven at $60^{\circ} \mathrm{C}$ for 2 days. The dried Field cricket was then ground to make powder with the help of a grinder and stored in a cold condition ($20^{\circ} \mathrm{C}$ ). The experiment was set up accordingly to a completely randomized design with six treatment of L-ascorbic acid, AA (99\%, Sigma-Aldrich, Germany). Supplementation was prepared to contain $0,10,20,30,40$ and $50 \mathrm{~g} \mathrm{AA} \mathrm{kg}^{-1}$ diet (dry matter basis, DM) with three replications. The composition of the main protein sources and experimental feed was confirmed by following the standard procedure for fish feed analysis (AOAC, 2003). Prepared feed samples were kept inside sealed bags and stored at $-20^{\circ} \mathrm{C}$ until used. The feed was formulated to contain iso-protein feed of average $57.8 \pm 0.2 \%$ protein and $4,999 \pm 10 \mathrm{kcal} \mathrm{kg}^{-1}$ gross energy diets with include $60 \mathrm{mg} \mathrm{MT}$ hormone (97\% (HPLC), Sigma-Aldrich, Germany) per kg feed and conducted for 21 days, fed five times per day. All experimental diets ( $\mathrm{T} 1$ to T6) which contained the same ratio of fish meal (FM) and FCM. Formulation and chemical composition of all the experimental SRT diets are shown in Table 2. 
Table 2 Formulation and chemical composition of the SRT diets (21 days)

\begin{tabular}{|c|c|c|c|c|c|c|}
\hline \multicolumn{7}{|c|}{ Increasing L-ascorbic acid amount $(\mathrm{g} / \mathrm{kg})$} \\
\hline Ingredients & $0(T 1)$ & $10(T 2)$ & $20(T 3)$ & 30 (T4) & 40 (T5) & $50(T 6)$ \\
\hline FCM $(g)$ & 78.96 & 78.96 & 78.96 & 78.96 & 78.96 & 78.96 \\
\hline $\mathrm{FM}(\mathrm{g})$ & 19.74 & 19.74 & 19.74 & 19.74 & 19.74 & 19.74 \\
\hline Vit C ( $(\mathrm{g} / \mathrm{kg})$ & 0 & 10.0 & 20.0 & 30.0 & 40.0 & 50.0 \\
\hline Vit $\operatorname{mix}(g)^{2}$ & 0.3 & 0.3 & 0.3 & 0.3 & 0.3 & 0.3 \\
\hline Mineral (g) 1 & 1.0 & 1.0 & 1.0 & 1.0 & 1.0 & 1.0 \\
\hline Alcohol (mL) & 12.0 & 12.0 & 12.0 & 12.0 & 12.0 & 12.0 \\
\hline $\mathrm{MT}(\mathrm{mL})$ & 12.0 & 12.0 & 12.0 & 12.0 & 12.0 & 12.0 \\
\hline Total & 100.0 & 100.0 & 100.0 & 100.0 & 100.0 & 100.0 \\
\hline \multicolumn{7}{|c|}{ Nutrient level determined by as is basis (\% dry matter basis) } \\
\hline DM (\%) & $90.6 \pm 0.0^{a}$ & $90.5 \pm 0.0^{a}$ & $90.0 \pm 0.0^{\mathrm{bc}}$ & $90.1 \pm 0.0^{b}$ & $89.9 \pm 0.0^{c}$ & $89.9 \pm 0.1^{b c}$ \\
\hline Moist. (\%) & $9.4 \pm 0.0^{\mathrm{a}}$ & $9.5 \pm 0.1^{\mathrm{a}}$ & $10.0 \pm 0.0^{b c}$ & $9.9 \pm 0.0^{b}$ & $10.1 \pm 0.0^{c}$ & $10.1 \pm 0.1^{b c}$ \\
\hline CP (\%) & $57.8 \pm 0.1^{a}$ & $57.7 \pm 0.2^{a}$ & $57.8 \pm 0.8^{a}$ & $57.6 \pm 0.1^{a}$ & $57.8 \pm 1.0^{a}$ & $57.8 \pm 0.3^{2}$ \\
\hline CL (\%) & $16.3 \pm 0.1^{a}$ & $16.4 \pm 0.0^{a}$ & $16.4 \pm 0.5^{a}$ & $16.3 \pm 0.4^{a}$ & $16.4 \pm 0.1^{a}$ & $16.3 \pm 0.3^{a}$ \\
\hline CF (\%) & $5.5 \pm 0.1^{a}$ & $5.5 \pm 0.2^{a}$ & $5.4 \pm 0.1^{a}$ & $5.4 \pm 0.0^{a}$ & $5.4 \pm 0.1^{a}$ & $5.2 \pm 0.0^{a}$ \\
\hline NFE 3 & $3.9 \pm 0.2^{a}$ & $4.1 \pm 0.8^{a}$ & $4.5 \pm 2.3^{a}$ & $5.3 \pm 1.4$ & $5.0 \pm 0.2$ & $5.2 \pm 1.0^{a}$ \\
\hline CA (\%) & $16.5 \pm 0.1^{\mathrm{c}}$ & $16.2 \pm 0.2^{\mathrm{bc}}$ & $15.9 \pm 0.1^{\mathrm{ab}}$ & $15.6 \pm 0.2^{a}$ & $15.3 \pm 0.1^{a}$ & $15.5 \pm 0.1^{a}$ \\
\hline $\mathrm{GE}^{4}(\mathrm{~kJ} / \mathrm{kg})$ & $4963 \pm 5^{a}$ & $4978 \pm 6^{a}$ & $4997.1 \pm 44^{a}$ & $5015 \pm 37^{a}$ & $5024 \pm 7^{a}$ & $5017 \pm 11^{a}$ \\
\hline
\end{tabular}

$\mathrm{DM}=$ Dry matters; SRT $=$ Sex reversal treatment; Moist. = Moisture; $\mathrm{CP}=$ Crude protein; $\mathrm{CL}=\mathrm{Crude}$ lipid; $\mathrm{CF}=\mathrm{Crude}$ fiber; $C A=$ Crude ash.

1 Mineral premix ( $\mathrm{g} / \mathrm{kg}$ of diet): calcium biphosphate, $20 \mathrm{~g}$; sodium chloride, $2.6 \mathrm{~g}$; potassium chloride, $5 \mathrm{~g}$; magnesium sulphate, $2 \mathrm{~g}$; ferrous sulphate, $0.9 \mathrm{~g}$; zinc sulphate, $0.06 \mathrm{~g}$; cupric sulphate, $0.02 \mathrm{~g}$; manganese sulphate, $0.03 \mathrm{~g}$; sodium selenite, $0.02 \mathrm{~g}$; cobalt chloride, $0.05 \mathrm{~g}$; potassium iodide, $0.004 \mathrm{~g}$.

${ }^{2}$ Vitamin mixture (IU or $\mathrm{mg} / \mathrm{kg}$ of diet): vitamin A, 500,000 IU; vitamin D3, 100,000 IU; vitamin E, 10,000 IU; vitamin $\mathrm{K}, 800 \mathrm{mg}$; vitamin $\mathrm{B} 1,250 \mathrm{mg}$; vitamin B2, $1200 \mathrm{mg}$; vitamin B6, $750 \mathrm{mg}$; vitamin B12, $5 \mathrm{mg}$; vitamin B5, $3000 \mathrm{mg}$; vitamin B3, $2150 \mathrm{mg}$; biotin, $25 \mathrm{mg}$; folic acid, $300 \mathrm{mg}$; inositol, 25,000 mg; Selenium, $30 \mathrm{mg;}$ Iron, 20,000 mg; Zinc, 32,000 mg; Copper, $2000 \mathrm{mg}$. Values for each experiment group in the same row followed by different superscripts are significantly $(P<0.05)$ different.

${ }^{3}$ Nitrogen free extract (NFE) $=100-($ crude protein $\%+$ crude lipid $\%+$ crude fiber $\%+$ total ash $\%)$.

${ }^{4}$ Gross energy (GE) was calculated according to NRC (1993) as 5.65, 9.45, and $4.11 \mathrm{kcal} / \mathrm{g}$ for protein, lipid, and carbohydrate, respectively.

After 21 days of hormone feeding, fish were nursed for another 91 days fed with diets containing $40.3 \pm 0.1 \%$ protein and $5,122 \pm 16 \mathrm{~kJ} / \mathrm{kg}$ gross energy formulated adding mainly rice bran with the same ratio of fish meal (FM) and FCM. Chromic oxide was also included to assess the digestibility. The diets were prepared by mixing dry ingredients and proximate composition of each diet are given in Table 3. Experimental diets were prepared in the lab using simple mincer machine and dried at $50^{\circ} \mathrm{C}$ for 48 hours in an electric oven. Final pellets were kept in sealed bags and stored at $-20^{\circ} \mathrm{C}$ until they were used. 
Table 3 Formulation and chemical composition of the nursery diets

\begin{tabular}{|c|c|c|c|c|c|c|}
\hline \multicolumn{7}{|c|}{ Increasing vitamin C amount $(\mathrm{g} / \mathrm{kg})$} \\
\hline Ingredients & $O(T 1)$ & $10(T 2)$ & $20(T 3)$ & $30(T 4)$ & $40(T 5)$ & $50(T 6)$ \\
\hline FCM $(\mathrm{g})$ & 30.6 & 30.6 & 30.6 & 30.6 & 30.6 & 30.6 \\
\hline FM (g) & 7.6 & 7.6 & 7.6 & 7.6 & 7.6 & 7.6 \\
\hline Rice bran (g) & 60.0 & 60.0 & 60.0 & 60.0 & 60.0 & 60.0 \\
\hline Vit C $(\mathrm{g} / \mathrm{kg})$ & 0 & 10.0 & 20.0 & 30.0 & 40.0 & 50.0 \\
\hline Vit. mix (g) & 0.3 & 0.3 & 0.3 & 0.3 & 0.3 & 0.3 \\
\hline Mineral (g) & 1.0 & 1.0 & 1.0 & 1.0 & 1.0 & 1.0 \\
\hline $\mathrm{Cr}_{2} \mathrm{O}_{3}(\mathrm{~g})$ & 0.5 & 0.5 & 0.5 & 0.5 & 0.5 & 0.5 \\
\hline Total & 100.0 & 100.0 & 100.0 & 100.0 & 100.0 & 100.0 \\
\hline \multicolumn{7}{|c|}{ Nutrient level determined by as is basis (\% dry matter basis) } \\
\hline Moist. (\%) & $94.8 \pm 0.0^{c}$ & $93.9 \pm 0.0^{d}$ & $93.7 \pm 0.0^{\mathrm{e}}$ & $96.3 \pm 0.1^{\mathrm{a}}$ & $95.0 \pm 0.0^{c}$ & $95.3 \pm 0.0^{\mathrm{b}}$ \\
\hline DM (\%) & $5.2 \pm 0.0^{c}$ & $6.1 \pm 0.0^{\mathrm{b}}$ & $6.3 \pm 0.0^{\mathrm{a}}$ & $3.6 \pm 0.1^{\mathrm{e}}$ & $5.0 \pm 0.0^{c}$ & $4.7 \pm 0.0^{\mathrm{d}}$ \\
\hline $\mathrm{CP}(\%)$ & $40.3 \pm 0.4^{\mathrm{ab}}$ & $40.7 \pm 0.1^{\mathrm{b}}$ & $40.9 \pm 0.2^{b}$ & $39.7 \pm 0.2^{\mathrm{a}}$ & $40.0 \pm 0.1^{\mathrm{ab}}$ & $40.1 \pm 0.1^{\mathrm{ab}}$ \\
\hline $\mathrm{CL}(\%)$ & $19.2 \pm 0.1^{\mathrm{b}}$ & $18.3 \pm 0.1^{\mathrm{b}}$ & $18.4 \pm 0.3^{b}$ & $18.9 \pm 0.3^{b}$ & $16.8 \pm 0.3^{a}$ & $16.5 \pm 0.3^{\mathrm{a}}$ \\
\hline$C(\%)$ & $6.2 \pm 0.1^{\mathrm{ab}}$ & $6.0 \pm 0.1^{a}$ & $6.1 \pm 0.0^{\mathrm{ab}}$ & $6.0 \pm 0.1^{\mathrm{ab}}$ & $6.2 \pm 0.0^{\mathrm{ab}}$ & $6.2 \pm 0.0^{\mathrm{b}}$ \\
\hline NFE & $24.2 \pm 0.4^{\mathrm{a}}$ & $24.4 \pm 0.3^{\mathrm{ab}}$ & $24.1 \pm 0.5^{\mathrm{a}}$ & $26.0 \pm 0.2^{\mathrm{bc}}$ & $27.2 \pm 0.3^{c}$ & $27.6 \pm 0.2^{c}$ \\
\hline $\mathrm{CA}(\%)$ & $9.1 \pm 0.5^{\mathrm{a}}$ & $9.5 \pm 0.1^{\mathrm{a}}$ & $9.3 \pm 0.4^{a}$ & $8.6 \pm 0.1^{\mathrm{a}}$ & $8.9 \pm 0.1^{a}$ & $8.8 \pm 0.1^{\mathrm{a}}$ \\
\hline $\mathrm{GE}(\mathrm{kJ} / \mathrm{kg})$ & $5184 \pm 22^{b}$ & $5138 \pm 8^{b}$ & $5161 \pm 29^{b}$ & $5164 \pm 13^{b}$ & $5048 \pm 14^{a}$ & $5034 \pm 17^{a}$ \\
\hline
\end{tabular}

Sex determination

Nursing period was continued another 91 days until they reached $10 \pm 2 \mathrm{~g}$ of fish which were dissected and isolated male (testes) and female (ovary) gonads (male: testes and Female: ovary). A small piece of gonad was placed on a slide and poured a drop of indigocarmine stain (Guerrero and Shelton, 1974) and allowed to develop the color. Then observed under simple microscope (Huma Scope Advanced LED 40X power with 0.5X CCD adapter)

\section{Histological analysis}

From each treatment three fish were sampled, dissected, their testes were isolated, immediately fixed in Bouin's solution for 48 hours and then transferred to $70 \%$ alcohol solution. Afterwards, the samples were dehydrated in a series of alcohol solutions, placed in xylene and then embedded in paraffin. Tissue blocks were sectioned and stained with hematoxylin and eosin. Tissue sections were observed under CX 31 Olympus (Japan) microscope.

\section{Fish growth and feed utilization}

At the end of each phase of both the experiments, fish were counted and weighted in each tank to calculate fish survival rate, final weight (FW), weight gain (WG), specific growth rate (SGR), feed conversion ratio (FCR), feed conversion efficiency (FCE), and protein efficiency ratio (PER). All the values were average of the triplicates for each treatment.

\section{Proximate analysis of diets and fish}

The feed ingredients formulated diets and whole fish body samples from each treatment at the initial and final days were analyzed for proximate composition (moisture, crude protein, total lipid, total ash, and total fiber) using the standard method of AOAC (2003). For instance, moisture content was estimated as the loss in weight after drying the samples at $105^{\circ} \mathrm{C}$ in a dry air oven. Total ash was determined by incineration at $550^{\circ} \mathrm{C}$ for 12 hours. Total nitrogen was determined by Kjeldahl apparatus and crude protein was estimated by multiplying the nitrogen content by 6.25 after. Crude lipid content was determined by the Soxhlet extraction. Crude fiber was analyzed under the Weende method using the Fibertec $^{\mathrm{TM}}$ system. 


\section{Blood sampling}

Six fish from each replicate group (45 fish/aquarium) were randomly selected after 90 days of feeding and anesthetized using $60 \mathrm{mg} / \mathrm{L}$ of MS222 (Ethyl 3-aminobenzoate methane sulfonate). Hematological studies were done collecting blood samples in a sterile $1 \mathrm{~mL}$ syringe from the caudal vein of each fish and inserted to EDTA coated tubes. Serum was separated from the bloods centrifuging at $3500 \mathrm{xg}$ for $15 \mathrm{~min}$ and stored at $-20^{\circ} \mathrm{C}$ until analysis. Another set of blood sample was added into Eppendorf tube and kept on slanting position for 12-18 hours in room temperature. Serum samples were taken from top layer by using pipette. All blood and serum samples were sent to Thai Vet Lab Co. Ltd to check CBC (cells blood count) and total protein amount. Mean corpuscular volume (MCV), mean corpuscular hemoglobin $(\mathrm{MCH})$, mean corpuscular hemoglobin concentration (MCHC) were calculated.

\section{Apparent digestibility $(A D)$}

Fecal collection was done 2 weeks after the stocking of fish and continued daily for 14 days. Tanks were fully cleaned 30 min after the afternoon meal. Feces were collected daily, before each morning meal. Uncontaminated fecal matters were gently siphoned off from the tanks onto a filter with bolting silk cloth, then it gently rinsed in distilled water, dried on a foil and collected and dried at $50^{\circ} \mathrm{C}$. Random samples of feed and feces from each replicate were subjected to chemical analysis of crude protein, crude lipid and chromic oxide content (AOAC, 2003) in triplicate. Acid digestion method was used to analyze chromic oxide content in feces and diets and absorbance was measured using spectrophotometer at wavelength of $350 \mathrm{~nm}$. Apparent Digestibility Coefficient (ADC) of protein and ADC of lipid were computed as follows.

$\%$ Chromic oxide content $=\mathrm{X} / \mathrm{W}_{0} \times 100$

Where, $X=$ Weight of chromic oxide in the sample $(\mathrm{mg}), W_{0}=$ Weight of the sample $(\mathrm{mg})$

$X=\frac{Y-0.0032}{0.2089}$

Where, $\mathrm{Y}=$ Absorbance $($ at $350 \mathrm{~nm}$ )

$$
\begin{aligned}
\text { ADC of Protein } \% & =100-100 \times \frac{(\% \text { chromic oxide in diet } \times \% \text { protein in faeces })}{(\% \text { chromic oxide in faeces } \times \% \text { protein in diet })} \\
\text { ADC of Lipid } \% & =100-100 \times \frac{(\% \text { chromic oxide in diet } \times \% \text { lipid in faeces })}{(\% \text { chromic oxide in faeces } \times \% \text { lipid in diet })}
\end{aligned}
$$

\section{Salinity challenge test}

LC 50 value was determined as $24 \mathrm{ppt}$, with dipping 2-hour period with 10 fishes with different salinity concentration as $0,6,12,18,24$, and 30ppt with triplicates. Challenge test was carried out taking $24 \mathrm{ppt}$ ( $\mathrm{LC}_{50}$ value) and run for 3 hours with continuous monitoring and counting of dead fish.

\section{Water quality analysis}

Water $\mathrm{pH}$, temperature, and dissolved oxygen (DO) were monitored daily at 08:30h. Dissolved oxygen was measured with a dissolved oxygen meter (Cyberscan DO, 110 RS232 model). Temperature and $\mathrm{pH}$ were measured using a pH meter (Cyberscan pH11 model). Water samples were collected to analyze ammonia concentration using the phenate method and nitrite using spectrophotometer (APHA, 2003). Experimental site was controlled to have 12-12 light-dark photoperiod cycle using fluorescent tubes. 


\section{Data analysis}

The SPSS 22.0 statistical package for social sciences (SPSS Inc.) was used for multiple comparisons among several means, all at 5\% significance level. All means are presented with \pm standard error (SE). One-way analysis of variance (ANOVA) was carried out to see the effects of factor/vitamin C dose followed by Tukey HSD for comparisons. Regression analysis was used to see the relationship between the variables and the vitamin $C$ doses, thereby to determine dietary vitamin $\mathrm{C}$ dose which resulted in maximum levels in response variables.

\section{Growth and survival}

\section{Results}

Results of the first trial are presented in Table $\mathbf{4}$ which showed that vitamin $\mathrm{C}$ improved survival and growth parameters when fed 10 and $20 \mathrm{~g} / \mathrm{kg}$ of diet. Beyond that level, negative effects were seen leading to abnormal swimming patterns and spinal deformity of in fry were observed at the highest dose of vitamin C. Results from the feeding trial during the 21 days, initial fish weight $(0.01 \pm 0.0 \mathrm{~g})$ and protein intake (range 21.76-21.82) were not significantly $(P>0.05)$ different, but final body weight (ranged $0.11-0.15 \mathrm{~g}$ ) of fish significantly $(P<0.05)$ affected by vitamin $C$ dose. Effects of vitamin $C$ on the growth and feed utilization (SRT period) are presented in Table 4.

Table 4 Growth performance of fish fed with experiment during the SRT period (21 days).

\begin{tabular}{|c|c|c|c|c|c|c|c|}
\hline \multirow{2}{*}{$S R T$} & \multicolumn{7}{|c|}{ Increasing levels of L-ascorbic acid ( $\mathrm{g} / \mathrm{kg}$ of feed) } \\
\hline & $0(T 1)$ & $10(T 2)$ & $20(T 3)$ & $30(T 4)$ & $40(T 5)$ & $50(T 6)$ & $P$-value \\
\hline IW (mg/fish) & $0.01 \pm 0.0^{\mathrm{a}}$ & $0.01 \pm 0.0^{\mathrm{a}}$ & $0.01 \pm 0.0^{\mathrm{a}}$ & $0.01 \pm 0.0^{\mathrm{a}}$ & $0.01 \pm 0.0^{\mathrm{a}}$ & $0.01 \pm 0.0^{\mathrm{a}}$ & $>0.05$ \\
\hline FW (g/fish) & $0.12 \pm 0.0^{\mathrm{a}}$ & $0.15 \pm 0.0^{\mathrm{ab}}$ & $0.13 \pm 0.0^{\mathrm{a}}$ & $0.12 \pm 0.0^{\mathrm{a}}$ & $0.11 \pm 0.0^{\mathrm{a}}$ & $0.11 \pm 0.0^{\mathrm{a}}$ & $<0.001$ \\
\hline Survival $(\%)^{1}$ & $67.1 \pm 3.1^{\mathrm{a}}$ & $85.4 \pm 0.9^{c}$ & $78.4 \pm 2.6^{\mathrm{bc}}$ & $79.6 \pm 0.6^{\mathrm{bc}}$ & $73.3 \pm 2.2^{\mathrm{ab}}$ & $73.1 \pm 1.8^{\mathrm{ab}}$ & 0.001 \\
\hline WG $(g / \text { fish })^{2}$ & $0.10 \pm 0.4^{\mathrm{ab}}$ & $0.13 \pm 1.8^{\mathrm{c}}$ & $0.11 \pm 3.3^{b}$ & $0.10 \pm 0.0^{\mathrm{ab}}$ & $0.10 \pm 0.0^{\mathrm{a}}$ & $0.10 \pm 0.0^{\mathrm{a}}$ & $<0.001$ \\
\hline SGR (\%) ${ }^{3}$ & $10.4 \pm 0.0^{\mathrm{ab}}$ & $11.4 \pm 0.0^{c}$ & $10.7 \pm 0.1^{b}$ & $10.3 \pm 0.1^{\mathrm{a}}$ & $10.2 \pm 0.1^{\mathrm{a}}$ & $10.2 \pm 0.1^{\mathrm{a}}$ & $<0.001$ \\
\hline $\mathrm{FCR}^{4}$ & $1.73 \pm 0.1^{\mathrm{d}}$ & $1.02 \pm 0.0^{\mathrm{a}}$ & $1.32 \pm 0.1^{\mathrm{b}}$ & $1.45 \pm 0.1^{\mathrm{bc}}$ & $1.63 \pm 0.1^{\mathrm{cd}}$ & $1.62 \pm 0.0^{\mathrm{cd}}$ & $<0.001$ \\
\hline $\mathrm{FCE}^{5}$ & $0.58 \pm 0.0^{\mathrm{a}}$ & $0.98 \pm 0.0^{c}$ & $0.76 \pm 0.0^{\mathrm{b}}$ & $0.69 \pm 0.0^{\mathrm{ab}}$ & $0.62 \pm 0.0^{\mathrm{a}}$ & $0.62 \pm 0.0^{\mathrm{a}}$ & $<0.001$ \\
\hline PI 6 & $21.8 \pm 0.0^{a}$ & $21.8 \pm 0.1^{\mathrm{a}}$ & $21.8 \pm 0.3^{a}$ & $21.8 \pm 0.2^{\mathrm{a}}$ & $21.8 \pm 0.4^{\mathrm{a}}$ & $21.8 \pm 0.2^{\mathrm{a}}$ & $>0.05$ \\
\hline $\mathrm{PER}^{7}$ & $0.91 \pm 0.0^{a}$ & $1.53 \pm 0.0^{c}$ & $1.19 \pm 0.1^{\mathrm{b}}$ & $1.08 \pm 0.0^{\mathrm{ab}}$ & $0.96 \pm 0.0^{a}$ & $0.96 \pm 0.0^{\mathrm{a}}$ & $<0.001$ \\
\hline
\end{tabular}

IW=Initial weight; $F W=$ Final weight; $D W G=$ Daily weight gain; $S G R=$ specific growth rate; $F C R=$ Feed conversion ratio; $\mathrm{FCE}=$ feed conversion efficiency; $\mathrm{PER}=$ protein efficiency ratio; $\mathrm{SGR}=$ specific growth rate; WG=weight gain

1. Survival of fish $=$ (Final number / Initial number $) \times 100$

2. Body weight gain $=$ Final weight $(\mathrm{g})$ - Initial weight $(\mathrm{g})$

3. Specific growth rate (SGR, \%/day) $=$ (Ln Weight at harvest - Ln Weight at stocking) / (number of days) $\times 100$

4. Feed conversion ratio $(F C R)=$ Feed intake in dry matter/Wet weight gain

5. Feed efficiency ratio $(F C E)=$ Wet weight gain/ Feed intake in dry matter

6. Protein intake $(\mathrm{PI})=$ Protein $\%$ of diet $\times$ amount of diet $(\mathrm{g})$

7. Protein Efficiency ratio $(P E R)=$ Wet weight gain / Protein intake in feed

Improvements were also seen in weight gain (WG), specific growth (SGR), protein efficiency ratio (PER) and feed conversion efficiency (FCE) with the increase in the vitamin $C$ dose when supplemented at $10 \mathrm{~g} / \mathrm{kg}$ diet as compared to the control. However, with the increasing dose, the relationship was polynomial quadratic in nature, which vitamin $C$ dose ranged as 10-20 g L-ascorbic acid during the SRT period. Average survival of tilapia ranged from 67.1 to $85.4 \%$ during the SRT period, significant $(P<0.05)$ differences were seen only between the treatments with the doses of 10 and $20 \mathrm{~g} / \mathrm{kg}$ diet with the control. During the SRT, relationships were polynomial for survival $\left(Y=0.001 x^{3}-0.0926 x^{2}+2.1853 x+68.138\right.$, $\left.R^{2}=0.82\right)$ and SGR $\left(Y=0.00009 x^{3}-0.0069 x^{2}+0.1268 x+10.476, R^{2}=0.84\right)$. Survival and SGR peaked at the dietary supplementation of vitamin $C$ at $15.86 \mathrm{~g}$ and $12.02 \mathrm{~g} / \mathrm{kg}$ diet, respectively. However, the highest $(P<0.05)$ protein efficiency ratio $(P E R)$ and lowest FCR were at $10 \mathrm{~g}$ vitamin $\mathrm{C} / \mathrm{kg} \operatorname{diet}(\mathrm{T} 2)$. 
Table 5 Growth performance of fish fed with experiment during nursing period (30 days).

\begin{tabular}{lrrrrrrr}
\hline \multirow{2}{*}{ Nursing } & \multicolumn{7}{c}{ Increasing levels of L-ascorbic acid $(\mathrm{g} / \mathrm{kg}$ of feed $)$} \\
\cline { 2 - 8 } & $0(T 1)$ & $10(T 2)$ & $20(T 3)$ & $30(T 4)$ & $40(T 5)$ & $50(T 6)$ & $\begin{array}{r}P- \\
\text { value }\end{array}$ \\
\hline IW (mg/fish) & $0.14 \pm 0.0^{\mathrm{a}}$ & $0.14 \pm 0.0^{\mathrm{a}}$ & $0.14 \pm 0.0^{\mathrm{a}}$ & $0.14 \pm 0.0^{\mathrm{a}}$ & $0.14 \pm 0.0^{\mathrm{a}}$ & $0.14 \pm 0.0^{\mathrm{a}}$ & 0.734 \\
FW (g/fish) & $0.39 \pm 0.0^{\mathrm{b}}$ & $0.45 \pm 0.0^{\mathrm{c}}$ & $0.41 \pm 0.0^{\mathrm{b}}$ & $0.39 \pm 0.0^{\mathrm{ab}}$ & $0.39 \pm 0.0^{\mathrm{ab}}$ & $0.37 \pm 0.0^{\mathrm{a}}$ & $<0.001$ \\
Survival (\%) & $67.6 \pm 1.6^{\mathrm{a}}$ & $82.6 \pm 3.5^{\mathrm{b}}$ & $79.3 \pm 3.2^{\mathrm{b}}$ & $73.0 \pm 0.8^{\mathrm{ab}}$ & $72 . \pm 2.0^{\mathrm{ab}}$ & $73.5 \pm 1.8^{\mathrm{ab}}$ & $<0.05$ \\
WG (g/fish) & $0.25 \pm 0.0^{\mathrm{a}}$ & $0.31 \pm 0.0^{\mathrm{b}}$ & $0.27 \pm 0.0^{\mathrm{a}}$ & $0.24 \pm 0.0^{\mathrm{a}}$ & $0.25 \pm 0.0^{\mathrm{a}}$ & $0.23 \pm 0.0^{\mathrm{a}}$ & $<0.001$ \\
SGR (\%) & $4.65 \pm 0.0^{\mathrm{a}}$ & $4.47 \pm 0.2^{\mathrm{a}}$ & $4.29 \pm 0.2^{\mathrm{a}}$ & $4.36 \pm 0.1^{\mathrm{a}}$ & $4.57 \pm 0.2^{\mathrm{a}}$ & $4.24 \pm 0.3^{\mathrm{a}}$ & 0.645 \\
FCR & $2.87 \pm 0.2^{\mathrm{c}}$ & $1.63 \pm 0.0^{\mathrm{a}}$ & $2.14 \pm 0.1^{\mathrm{ab}}$ & $2.68 \pm 0.1^{\mathrm{bc}}$ & $2.46 \pm 0.0^{\mathrm{bc}}$ & $2.66 \pm 0.2^{\mathrm{bc}}$ & 0.001 \\
FCE & $0.35 \pm 0.0^{\mathrm{a}}$ & $0.61 \pm 0.0^{\mathrm{c}}$ & $0.47 \pm 0.0^{\mathrm{b}}$ & $0.37 \pm 0.0^{\mathrm{ab}}$ & $0.41 \pm 0.0^{\mathrm{ab}}$ & $0.38 \pm 0.0^{\mathrm{ab}}$ & $<0.001$ \\
PER & $0.83 \pm 0.1^{\mathrm{a}}$ & $1.42 \pm 0.0^{\mathrm{c}}$ & $1.08 \pm 0.1^{\mathrm{b}}$ & $0.91 \pm 0.0^{\mathrm{ab}}$ & $0.97 \pm 0.0^{\mathrm{ab}}$ & $0.91 \pm 0.1^{\mathrm{ab}}$ & $<0.001$ \\
\hline
\end{tabular}

Fish growth performance of Nile tilapia during 30 days of nursing are shown in Table $\mathbf{5}$. During the 30 days of experimental period, average survival of tilapia ranged from 67$83 \%$, the value for $10 \mathrm{~g} / \mathrm{kg}$ diet was significantly $(P<0.05)$ higher than that of control. Survival showed polynomial relationship with the peak at the doses between 10 and 20 $\mathrm{g} / \mathrm{kg}$ diet. Fish weights gain increased polynomial, which showed significantly higher weight gain in for $10 \mathrm{~g} / \mathrm{kg}$ diet $(0.31 \pm 0.0 \mathrm{~g})$ than other treatments when compared using Tukey's HSD test. Similar trends were also seen in case of protein efficiency ratio (PER) and feed conversion ratio (FCR).

\section{Proximate analysis of fish}

Proximate composition of the whole-body moisture, dry matter, and ash contents were not significant difference among the dietary treatments. But crude lipid, crude protein, Nitrogen free extract (NFE) and gross energy (GE) were significantly difference $(P<0.05)$ among the treatments. Carcass proximate composition of different feeding groups is presented in Table 6.

Table 6 Proximate composition (\% on dry matter basis) of the experimental fish (Mean $\pm \mathrm{SE}$ )

\begin{tabular}{|c|c|c|c|c|c|c|c|}
\hline & \multicolumn{6}{|c|}{ At the end of sex reversal - increasing vitamin C $(\mathrm{g} / \mathrm{kg}$ of feed) } & \multirow{2}{*}{ P-value } \\
\hline & $O(T 1)$ & $10(T 2)$ & $20(T 3)$ & $30(T 4)$ & $40(T 5)$ & $50(T 6)$ & \\
\hline DM & $86.25 \pm 0.4^{\mathrm{a}}$ & $86.84 \pm 0.3^{\mathrm{a}}$ & $86.10 \pm 0.3^{\mathrm{a}}$ & $86.31 \pm 0.6^{\mathrm{a}}$ & $86.14 \pm 0.5^{\mathrm{a}}$ & $86.52 \pm 0.7^{a}$ & 0.895 \\
\hline Ash & $17.59 \pm 0.2^{a}$ & $17.27 \pm 0.3^{a}$ & $16.66 \pm 0.3^{a}$ & $16.81 \pm 0.3^{a}$ & $16.46 \pm 0.3^{a}$ & $16.45 \pm 0.2^{\mathrm{a}}$ & 0.056 \\
\hline Lipid & $14.87 \pm 0.2^{\mathrm{b}}$ & $14.84 \pm 0.5^{\mathrm{b}}$ & $14.65 \pm 0.4^{\mathrm{b}}$ & $14.63 \pm 0.5^{b}$ & $14.07 \pm 0.0^{\mathrm{ab}}$ & $13.39 \pm 0.3^{\mathrm{a}}$ & 0.002 \\
\hline Protein & $56.39 \pm 0.0^{\mathrm{abc}}$ & $57.72 \pm 0.0^{\mathrm{bc}}$ & $57.79 \pm 0.1^{\mathrm{c}}$ & $56.6 \pm 0.1^{\mathrm{ab}}$ & $55.80 \pm 0.6^{a}$ & $55.37 \pm 1.3^{a}$ & 0.001 \\
\hline $\begin{array}{l}\mathrm{NFE}^{1} \\
\mathrm{GE}^{2}\end{array}$ & $\begin{array}{c}11.15 \pm 0.1^{\mathrm{a}} \\
5050 \pm 8^{\mathrm{ab}}\end{array}$ & $\begin{array}{l}0.17 \pm 0.1^{\mathrm{a}} \\
5082 \pm 10^{\mathrm{b}}\end{array}$ & $\begin{array}{c}10.91 \pm 1.0^{\mathrm{a}} \\
5097 \pm 0.7^{\mathrm{b}}\end{array}$ & $\begin{array}{c}12.4 \pm 0.5^{\mathrm{ab}} \\
5065 \pm 13^{\mathrm{b}}\end{array}$ & $\begin{array}{c}13.67 \pm 0.3^{\mathrm{bc}} \\
5044 \pm 21^{\mathrm{ab}}\end{array}$ & $\begin{array}{c}14.79 \pm 1.2^{c} \\
5001 \pm 39^{a}\end{array}$ & $\begin{array}{c}<0.001 \\
0.004\end{array}$ \\
\hline
\end{tabular}

Values for each experiment group in the same row followed by different superscripts are significantly $(P<0.05)$ different.

${ }^{1}$ Nitrogen free extract (NFE) $=100-$ (crude protein $\%+$ crude lipid $\%$ +crude fiber $\%+$ total ash $\%$ ).

${ }^{2}$ Gross energy (GE) (kJ/kg) was calculated according to NRC (1993) as 5.65, 9.45, and $4.11 \mathrm{kcal} / \mathrm{g}$ for protein, lipid, and carbohydrate, respectively.

DM=Dry matters

The crude lipid content of fed T1-T4 diet (ranged 14.63-14.87\%) were significantly higher than T6 diet $(13.39 \pm 0.3 \%)$. Similarly, gross energy was higher in diet T2-T4 (ranged 5,065-5,097 kJ/kg) compared with diet T6 $(5001 \pm 39)$. But the crude protein was higher in diet T3 $(57.79 \pm 0.1 \mathrm{~g})$ than diet T4-T6 (ranged 55.37-56.6 \%).

\section{Blood hematological parameters}

No significant difference was noticed in the RBC, WBC and $\mathrm{MCH}$ level among the experimental group ( $p>0.05)$. Conversely, the $\mathrm{Hct}, \mathrm{Hb}, \mathrm{MCV}, \mathrm{MCHC}$, and total protein (TP) were significant difference among the treatment $(P<0.05)$. Data of blood hematological parameters and serum protein were illustrated (Table 7). Hemoglobin ( $\mathrm{Hb}$ ) was significant 
between T1 either T2 diet compared with control. But Hct was significant at diet T2-T4

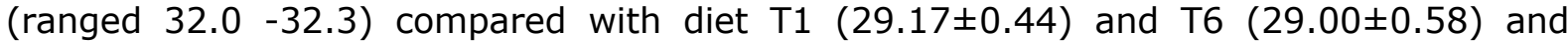
overdose of vitamin C not beneficial for fish immunity. Dietary vitamin C at T1-T3 diets lead to significant $(\mathrm{P}<0.05)$ increased of total protein in blood serum sample and it was significant lower at diet T1 $(2.63 \pm 0.09 \mathrm{~g} / \mathrm{dl})$ compared with diet T2-T3 (ranged 3.27-3.30 $\mathrm{g} / \mathrm{dl}$ ). Overall, dietary supplementation with T2 and T3 diets lead to significant increased blood hematological and serum biochemical measurements compared to other treatments.

Table 7 Hematological blood parameters of Nile tilapia fry fed dietary $0-50 \mathrm{~g}$ vitamin $\mathrm{C} / \mathrm{kg}$ diet.

\begin{tabular}{|c|c|c|c|c|c|c|c|}
\hline & \multicolumn{6}{|c|}{ Dietary vitamin C level ( $\mathrm{g} / \mathrm{kg}$ diet) } & \multirow{2}{*}{$\begin{array}{c}P- \\
\text { value }\end{array}$} \\
\hline & $O(T 1)$ & $10(T 2)$ & $20(T 3)$ & $30(T 4)$ & $40(T 5)$ & $50(T 6)$ & \\
\hline $\mathrm{RBC}^{1}$ & $2.49 \pm 0.0^{\mathrm{a}}$ & $2.55 \pm 0.0^{\mathrm{a}}$ & $2.44 \pm 0.0^{\mathrm{a}}$ & $2.43 \pm 0.0^{\mathrm{a}}$ & $2.44 \pm 0.0^{a}$ & $2.42 \pm 0.0^{\mathrm{a}}$ & $<0.05$ \\
\hline$W_{B C}{ }^{2}$ & $6900 \pm 100^{a}$ & $6883 \pm 16.7^{a}$ & $6900 \pm 57.7^{\mathrm{a}}$ & $6867 \pm 33.3^{\mathrm{a}}$ & $6900 \pm 57.7^{\mathrm{a}}$ & $6700 \pm 100^{\mathrm{a}}$ & 0.315 \\
\hline $\mathrm{Hb}^{3}$ & $10.6 \pm 0.1^{\mathrm{ab}}$ & $11.3 \pm 0.1^{\mathrm{c}}$ & $11.3 \pm 0.2^{\mathrm{c}}$ & $11.2 \pm 0.1^{\mathrm{bc}}$ & $11.0 \pm 0.1^{\mathrm{abc}}$ & $10.5 \pm 0.2^{\mathrm{a}}$ & 0.002 \\
\hline $\mathrm{Hct}^{4}$ & $29.2 \pm 0.4^{a}$ & $32.3 \pm 0.3^{\mathrm{b}}$ & $32.3 \pm 0.9^{b}$ & $32.0 \pm 0.6^{b}$ & $30.7 \pm 0.3^{\mathrm{ab}}$ & $29.0 \pm 0.6^{a}$ & 0.002 \\
\hline $\mathrm{MCV}^{5}$ & $117.2 \pm 3.6^{a}$ & $127 \pm 2.3^{\mathrm{ab}}$ & $132.4 \pm 4.9^{b}$ & $131.8 \pm 3.2^{\mathrm{ab}}$ & $125.6 \pm 2.3^{\mathrm{ab}}$ & $120.0 \pm 1.5^{\mathrm{ab}}$ & $<0.05$ \\
\hline $\mathrm{MCH}^{6}$ & $42.7 \pm 1.2^{\mathrm{a}}$ & $44.5 \pm 0.6^{a}$ & $46.3 \pm 1.1^{\mathrm{a}}$ & $46.1 \pm 0.8^{\mathrm{a}}$ & $44.9 \pm 0.7^{a}$ & $43.6 \pm 0.3^{a}$ & $>0.05$ \\
\hline $\mathrm{MCHC}^{7}$ & $36.5 \pm 0.2^{c}$ & $35.1 \pm 0.1^{\mathrm{ab}}$ & $35.0 \pm 0.5^{\mathrm{a}}$ & $35.0 \pm 0.3^{\mathrm{a}}$ & $35.8 \pm 0.2^{\mathrm{abc}}$ & $36.3 \pm 0.2^{\mathrm{bc}}$ & 0.05 \\
\hline $\mathrm{TP}^{8}$ & $2.63 \pm 0.1^{\mathrm{a}}$ & $3.27 \pm 0.1^{\mathrm{b}}$ & $3.30 \pm 0.2^{b}$ & $3.13 \pm 0.1^{\mathrm{ab}}$ & $2.93 \pm 0.1^{\mathrm{ab}}$ & $2.93 \pm 0.1^{\mathrm{ab}}$ & $<0.05$ \\
\hline
\end{tabular}

Values are mean \pm Standard error $(n=3)$. Values for each experiment group in the same row followed by different superscripts are significantly $(P<0.05)$ different.

${ }^{1} \mathrm{RBC}\left(\times 10^{6}\right.$ cell $\left.\mathrm{ML}\right)$ : Red blood cell.

${ }^{2}$ WBC $\left(\times 10^{6}\right.$ cell $\left.\mathrm{ML}\right)$ : White blood cell.

${ }^{3} \mathrm{Hb}(\mathrm{g} / \mathrm{dl})$ : Hemoglobin.

${ }^{4}$ Hct $(\%)$; Hematocrit.

${ }^{5} \mathrm{MCV}$ (Mean corpuscular volume): Hematocrit / Red blood cell.

${ }^{6} \mathrm{MCH}$ (Mean corpuscular hemoglobin): Hemoglobin content/ Red blood cell.

${ }^{7} \mathrm{MCHC}$ (Mean corpuscular hemoglobin concentration): Hemoglobin content / hematocrit.

${ }^{8} \mathrm{TP}(\mathrm{g} / \mathrm{dl})$ : Total protein.

\section{Apparent Digestibility (AD)}

The apparent digestibility (AD \%) of the protein and lipid are illustrated in Figure 1(a) and $1(\mathrm{~b})$, respectively. Polynomial relationship between treatment and apparent digestibility of protein as well as lipids were observed for all the parameters evaluated $(P<0.05)$. Polynomial regression analysis showed these values were highest between 10 and $20 \mathrm{~g} / \mathrm{kg}$ diet. ADC for protein was estimated around $84 \%$ at $15.36 \mathrm{~g}$ vitamin C/ $\mathrm{kg}$ diet and highest lipid was estimated around $91 \%$ at $17.75 \mathrm{~g}$ vitamin C per $\mathrm{kg}$ diet. 
(a)

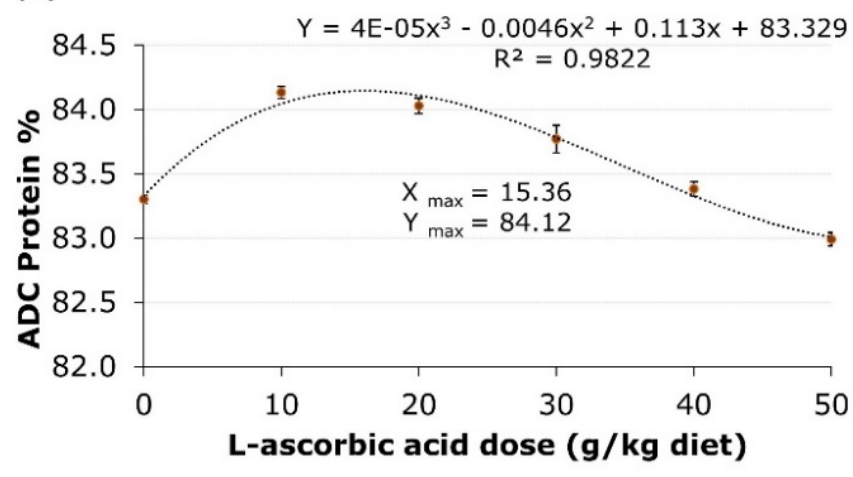

(b)

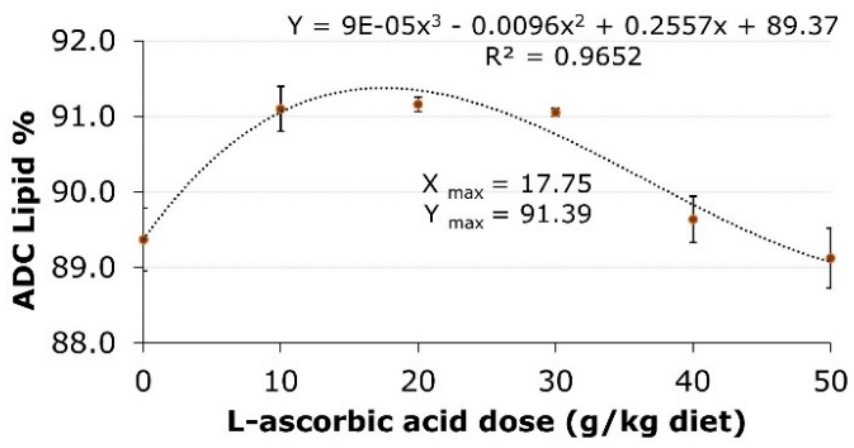

Figure 1 Apparent digestibility coefficient (\%) of protein (a) and lipid (b) with dietary ascorbic acid dose of the six diet just after sex-reversal treatment.

Sex-reversal percent

We used MT fed mixing with the diet for 21 days to produce mono sex tilapia fry. Gonad histology was observed (6 replicates /treatment) at the end of the trial i.e., 112 day (Figure 3) and remaining all tilapia gonad analyzed using gonad squash method at 112 days gives results in Table 8 .

Table 8 Percentage of male assessed by using gonad squash method after 112 days.

\begin{tabular}{lrrrrrr}
\hline \multirow{2}{*}{ \% male } & \multicolumn{5}{c}{ Increasing levels of vitamin C (g/kg of feed) } \\
\cline { 2 - 7 } & $0(T 1)$ & $10(T 2)$ & $20(\mathrm{~T} 3)$ & $30(\mathrm{~T} 4)$ & $40(\mathrm{T5})$ & $50(\mathrm{T6})$ \\
\hline Sample 1 & 100.0 & 99.3 & 99.2 & 99.1 & 99.1 & 99.2 \\
Sample 2 & 98.3 & 98.4 & 99.2 & 98.3 & 100.0 & 99.0 \\
Sample 3 & 99.0 & 99.3 & 100.0 & 98.2 & 99.1 & 98.2 \\
\hline Average & $99 \pm 0.5^{\mathrm{a}}$ & $99 \pm 0.3^{\mathrm{a}}$ & $99 \pm 0.3^{\mathrm{a}}$ & $98 \pm 0.3^{\mathrm{a}}$ & $99 \pm 0.3^{\mathrm{a}}$ & $99 \pm 0.3^{\mathrm{a}}$ \\
\hline
\end{tabular}

The average male percentage was $99.05 \pm 0.14 \%$ which is acceptable by the farmers. The sex-ratio of tilapia fry fed without vitamin C supplement was around $99 \%$ male which was not significantly $(P>0.05)$ different with other treatment. However, there was no significant variations in results among the treatments. Results illustrates that all treatments can be used for mono-sex tilapia production without considering the fish growth performance.

Concentration of spermatogonia increased while increasing in the vitamin C doses up to $30 \mathrm{~g} \mathrm{AA} / \mathrm{kg}$ diet as well as changes in testis color. However, at higher doses of vitamin C diets concentrated spermatogonia were seen along with little spermatogonia around (Figure 2). 

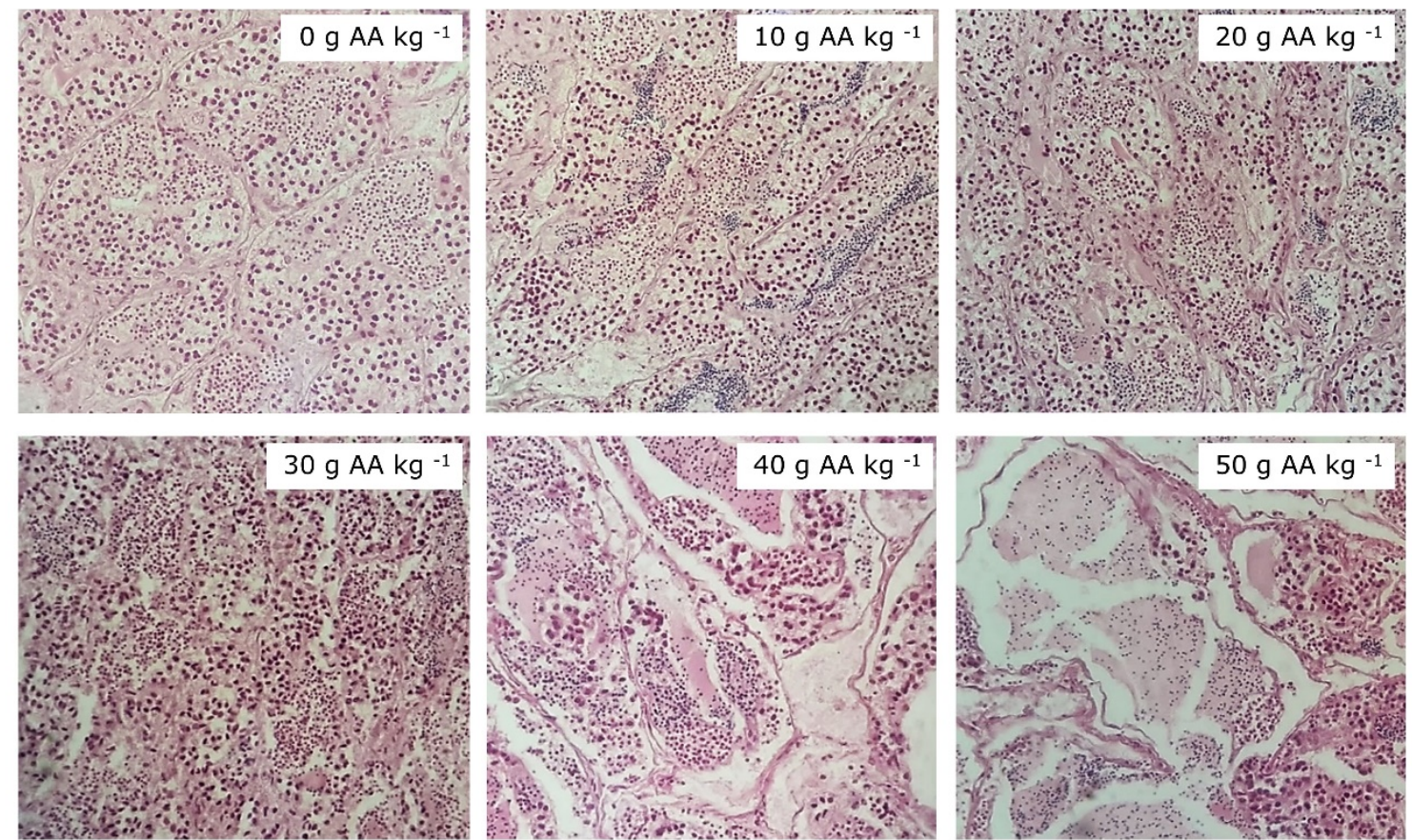

Figure 2 Representative histological pictures of Nile tilapia testes fed different dietary ascorbic acid level seen on the gonad sampled at $112^{\text {th }}$ day.

\section{Salinity stress test}

Survival when fry were exposed to high salinity i.e., $24 \mathrm{ppt}$ as determined as the $50 \%$ LC. Mortality occurred right from 3rd hour showing the signs of bleaching of skin near operculum and abdomen area L-ascorbic acid dose showed very clear effects on survival. However, highest survival reached average $86.4 \pm 1.7 \%$ survival at the dose between 10 and $20 \mathrm{~g} / \mathrm{kg}$ diet (Figure $\mathbf{3}$ ).

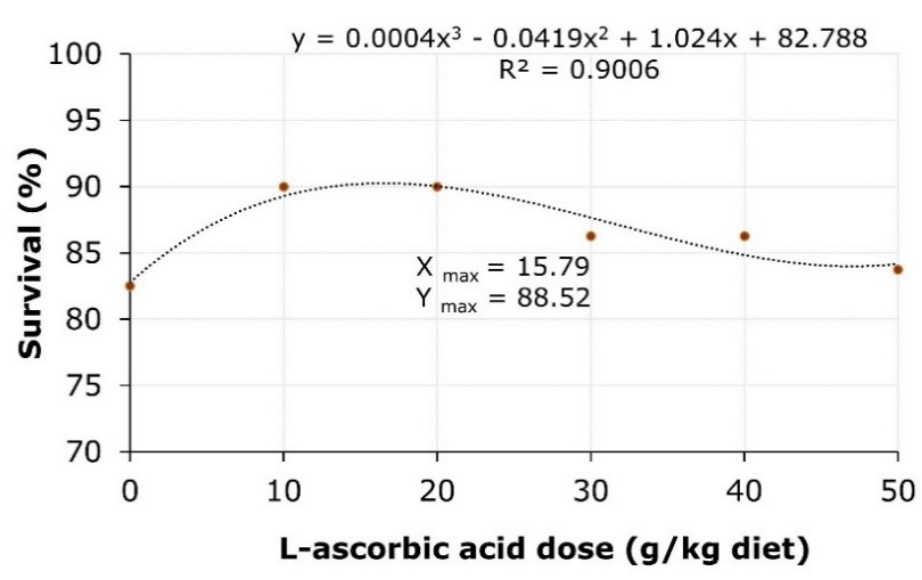

Polynomial regression analysis showed that the highest survival was obtained when the L-ascorbic acid dose was at $15.79 \mathrm{~g} \mathrm{AA} / \mathrm{kg}$ diet. Higher doses showed decline in survival.

Figure 3 Average survival after challenge with $24 \mathrm{ppt}$ salinity treatments for Nile tilapia fry.

\section{Water quality}

Average water temperature was $27.7^{\circ} \mathrm{C} \pm 0.08{ }^{\circ} \mathrm{C}$ with $12-12$ light-dark photoperiod cycle using fluorescent tubes as a light source. Dissolved oxygen concentration was average $6.09 \pm 0.02 \mathrm{mg} / \mathrm{L}$, the $\mathrm{pH}$ range $7.28 \pm 0.01$, ammonia concentration was $0.38 \pm 0.04 \mathrm{mg} / \mathrm{L}$ and nitrite concentration was $0.02 \pm 0.01 \mathrm{mg} / \mathrm{L}$. There was no significant difference in water quality parameters among the treatment. Therefore, all the water quality parameters acceptable ranges for Nile tilapia fry growth. 


\section{Discussion}

Vitamin C (L-ascorbic acid, AA) is an essential micronutrient to improve immunity, physiological functions (Ibrahem et al., 2010). The positive growth response (FW, WG, SGR, survival) and nutrient utilization (FCR, PER, ADC\% protein), salinity challenge, hematological responses ( $\mathrm{Hb}, \mathrm{Hct}, \mathrm{MCV}, \mathrm{MCHC})$ and serum biochemical measurement (Total protein) indicators of the fish fed 10 and $20 \mathrm{~g}$ vitamin $\mathrm{C}$ per $\mathrm{kg}$ feed were significantly higher than those fed control diet. Hence, the increased growth observed in the current study can be attributed to the multiple roles of ascorbic acid as reported for fish growth, nutrient utilization, protein metabolism and collagen formation (Kumari and Sahoo, 2005; Shahkar et al., 2015). It is not clear why the higher doses of vitamin C were detrimental. It is likely that excessive amount might have caused binding of other nutrients affecting the digestion and absorption of protein, lipids, and minerals. thereby negatively affecting the survival and growth, other parameters.

The amino acids profile and proximate composition of FCM show that it has adequate nutrients for fish growth, which are close to the values of earlier reports (Wang et al., 2005; Taufek et al., 2016a; 2017; Khan, 2018). Fish survival and growth, hematological indicators, and salinity challenge were reflection of the health status. During the sex reversal period, MT was used as a steroid hormone to produce mono-sex male tilapia. Survival rate of tilapia fry are considerably higher than earlier reports (Toyama et al., 2000; Suwanmanee et al., 2012). The improved survival rate of fry were indicated that the use of the FCM might have beneficial effects on immunity. This type of positive scenario represents due to the combinations of Vitamin $C$ and various nutrients and other factors. Among the nutrients, the insect meal may have high level of Vitamin D3 as they are exposed to sunlight. Moreover, the nutrient composition with the rich crude protein, the amino acid profile, and lipids, confirm the high-performance capacity of the FCM than the FM alone.

An earlier research has also reported that increment of ascorbic acid dose increased spermatogonia as well as color intensity (Shahkar et al., 2015), but higher dose of vitamin $C$ showed difference. Nevertheless, the percentage of male in all the treatments very high $(>98 \%)$ and are at acceptable levels for the industry which produce and supply mono-sex tilapia. The present study has also indicated that lower dose $(<30 \mathrm{~g} / \mathrm{kg}$ AA diet) might have positive effects on proliferation of spermatogonia, as well as higher doses $(>30 \mathrm{~g} / \mathrm{kg}$ AA diet) might have negative effects. Importantly, the histological observation of this study revealed that $L$-ascorbic acid $(A A)$ is mainly involved in gonadal development of male Nile tilapia during Sex-reversal treatment.

However, in case of SRT fish, alternative solution is needed to improve fish survival during the culture period that MT steroid might have any negative effect (Little et al., 2003; Ibrahem et al., 2010; Abo-Al-Ela et al., 2017). Present study showed higher dose i.e., $15.86 \mathrm{~g}$ of vitamin $\mathrm{C}$ per $\mathrm{kg}$ diet results in a higher survival, than that of earlier report. A dose of $4.9 \mathrm{~g} \mathrm{AA} / \mathrm{kg}$ diet was found to result in $75 \%$ fish survival (Suwanmanee et al., 2012). For larger tilapia, lower level of vitamin C diet (150 mg vitamin $\mathrm{C} / \mathrm{kg}$ diet) has been recommended i.e., for $800 \mathrm{~g}$ initial weight of Nile tilapia (Martins et al., 2016). Similarly, some of the authors have reported higher specific growth rate when given up to $1 \mathrm{~g}$ vit $\mathrm{C} / \mathrm{kg}$ diet compared with control fish (Tewary and Patra, 2007), $1.5-2 \mathrm{~g} / \mathrm{kg}$ diet in common carp (Labh et al., 2017; Faramarzi, 2016), and $3 \mathrm{~g}$ vitamin C/ $\mathrm{kg}$ was enhanced the antibody production in channel catfish ( $\mathrm{Li}$ and Lovell, 1985). By analyzing previously highlighted literature results and present research findings, clearly suggest that the small size of Nile tilapia needs higher doses of vitamin $C$ than bigger size tilapia. Although, present study used 17-a MT to convert all-male tilapia ( $99 \%$ or more); hence, the present study demonstrated that vitamin C in SRT diet might be a suitable solution to maintain immunity which might have disrupted from steroid hormone. 
Fish carcass composition especially moisture, ash, NFE and GE did not significantly differ in the present study. All though, it was not analyzed in the present study, an earlier report has shown elevated vitamin $C$ in the tissue while increasing vitamin $C$ in diet, a trend which is also observed in other species too (Wang et al., 2003; Shahakr et al., 2015). Salinity challenges indicate that ability to adapt to stress conditions, higher survival percentage of fish more tolerance to salinity, as well as stress condition (MacNiven and Little, 2001). Stress challenge occurs when predisposing factors are present such as abrupt temperature changes, and stress due to handling, crowding, and inadequate feed and oxygen (Yardimci and Aydin, 2011). An earlier report has suggested that leaching of vitamin $\mathrm{C}$ was increased with high water temperature and long immersion time (Soliman et al., 1987). Therefore, the water temperature has maintained between $27-29^{\circ} \mathrm{C}$ throughout this experiment, and other water quality parameters were controlled to present the optimum conditions. Due to this fact, farmers are suggested to maintain stable water quality and smooth handling of fish to maintain optimum level of vitamin $C$ in sex reversal tilapia production.

In the present study reported low level of RBC and WBC. Similar finding results of reported by Sayed and Moneeb (2015) with use of MT steroid hormone. Hemoglobin results also associate with fish health, higher hemoglobin value was shown in good health fish; Hemoglobin ( $\mathrm{Hb}), \mathrm{Hct}, \mathrm{MCV}$ and MCHC were significantly low in control treatment in present study and it was significantly higher with vitamin $\mathrm{C}$ mixed diet. These results have indicated that vitamin $C$ leaded to modulates the immunotoxin effect of 17-a MT in Nile tilapia (AboAl-Ela et al., 2017). Nevertheless, care needs to be taken or more research needs to be done as AA has been shown associated with anemic condition due to poor absorption and redistribution of iron, therefore, iron supplementation also most important to improve blood $\mathrm{Hb}$ (Shahkar et al., 2015). Hct values reflect the health status of fish that indicator for oxygen transportation capacity of fish, hence nutritional deficiency and diseases are always associated with low levels of Hct (El-Asely et al., 2014). Significantly higher hematocrit value and superoxide dismutase activity was found in fish fed higher vitamin $\mathrm{C} / \mathrm{kg}$ diet (Shahkar et al., 2015). In the present study, higher amount of serum total proteins was detected compared to control treatment, due to the significant positive effect of $10-20 \mathrm{~g}$ vitamin $\mathrm{C} / \mathrm{kg}$ diet. This scenario reflects the role of vitamin C included FCM diet, in enhancement of fish immunity response. Additionally, this helps to assess their potential benefits in Nile tilapia (Orechromis niloticus) production, during sex-reversal period.

There were limited publications on higher than $5 \mathrm{~g}$ dose of vitamin $\mathrm{C}$ with sex reversal treatment on tilapia. Based on the present study results, the dose higher than $5 \mathrm{~g} / \mathrm{kg}$ vitamin $C$ serves as a nutrient supplementation that can help enhance survival, and improve growth, feed utilization, stress resistance and sex differentiation that are major key indicators of mono-sex Nile tilapia fry. Research on the fishmeal replacement with insect meals or other products have been popular for other freshwater fish species. However, there were very limited information is available for tilapia. The results of the present study on the use of FCM, has proved that it is a potential source of animal protein that contains high level of nutrients comparable to fishmeal. Therefore, FCM with the supplementation of vitamin $\mathrm{C}$ diets of all male tilapia appears to be practical and viable provided that it is cultured on mass scale.

In conclusion, fish survival, growth and other parameters improved when vitamin $\mathrm{C}$ was supplemented at $10-20 \mathrm{~g} / \mathrm{kg}$. The doses higher than $20 \mathrm{~g} / \mathrm{kg}$ diet were not beneficial as per thought before. Regression analysis showed $15 \mathrm{~g}$ vitamin $\mathrm{C} / \mathrm{kg}$ is recommended when $80 \%$ fishmeal is replaced with FCM. More research is needed to see whether other vitamins, minerals or other factors could help enhance survival of tilapia fry further. 


\section{Acknowledgements}

This study was carried out as a part of PhD requirement of the first author funded by various project of Aqua-Center. The experiment was conducted using the aquaculture lab and Field facility of the Asian Institute of the Technology (AIT), Thailand. The authors would like to thank for providing facilities of Aquatic Animal Health and Research and Development Division (AAHRDD), Department of Fisheries (DOF) for histological analysis.

\section{References}

Abo-Al-Ela, H. G. 2018. Hormones and fish monosex farming: A spotlight on immunity. Animal Health Research Institute, Shibin Al-Kom Branch, Agriculture Research Centre, ElMinufiya, Egypt. Fish and Shellfish Immunology 72: 23-30. https://doi.org/10.1016/j.fsi.2017.10.038.

Abo-Al-Ela, H. G., El-Nahas, A., Mahmoud, S., Ibrahim, E., 2017. The extent to which immunity, apoptosis and detoxification gene expression interact with 17 alphamethyltestosterone. Fish and Shellfish Immunology 60: 289-298. https://doi.org/10.1016/j.fsi.2016.11.057.

AOAC. 2003. Association of Official Analytical Chemists (AOAC), Official methods of analysis of the association of official analytical chemists, 17th Edition, Washington DC.

Bhujel R.C., 2009. Artificial incubation, hormonal sex-reversal promoted tilapia boom. Global Advocate-Sept/Oct2009, 73-75pp.

Bhujel R.C., 2014. A Manual or Tilapia Hatchery \& Grow-out Farmers. CABI Publishing, Wallingford, UK. 216p.

Dabrowski, K., El-Fiky N., Koch, G., Frigg, M., Wieser, W., 1996. Requirement and utilization of AA and ascorbic acid sulphate in juvenile rainbow trout. Aquaculture 91: 317337. https://doi.org/10.1016/0044-8486(90)90197-U.

El-Asely A.M., Abbass, A.A., Austin, B., 2014. Honeybee pollen improves growth, immunity, and protection of Nile tilapia (Oreochromis niloticus) against infection with Aeromonas hydrophile. Fish Shellfish Immunology 40(2): 500-506. https://doi.org/10.1016/j.fsi.2014.07.017.

El-Sayed, A.M., Teshima, S.I., 1992. Protein and energy requirements of Nile tilapia, Oreochromis niloticus, fry. Aquaculture 103: 55- 63. https://doi.org/10.1016/00448486(92)90278-S.

Eo, J., Lee, K.J., 2008. Effect of dietary ascorbic acid on growth and non-specific immune response of tiger puffer, Takifugu rubripes. Fish Shellfish Immunology 25: 611-616. https://doi.org/10.1016/j.fsi.2008.08.009.

FAO. 2013. Edible insects: future prospect for food and feed security. FAO Forestry Paper 171p. http://www.fao.org/3/i3253e/i3253e.pdf.

Faramarzi, M., 2012. Effect of dietary vitamin C on growth and feeding parameters, carcass composition and survival rate of Common Carp (Cyprinus carpio). Global Veterinaria 8: 507-510.

Guerrero, R.D., Shelton, W.L., 1974. An aceto-carmine squash technique for sexing juvenile fishes. The Progressive Fish-Culturist. 36: p.56. https://doi.org/10.1577/15488659(1974)36[56:AASMFS]2.0.CO;2.

Ibrahem, M.D., Fathi, M., Mesalhy, S., Abd El-Aty, A.M., 2010. Effect of dietary supplementation of inulin and vitamin $\mathrm{C}$ on the growth, hematology, innate immunity, and resistance of Nile tilapia (Oreochromis niloticus), Fish \& Shellfish Immunology 29(2): 241246. https://doi.org/10.1016/j.fsi.2010.03.004.

Jiménez-Fernández, E., Ponce, M., Rodriguez-Rúa, A., Zuasti, E., Manchado, M., Fernández-Díaz, C., 2015. Effect of dietary vitamin C level during early larval stages in Senegalese sole (Solea senegalensis). Aquaculture 443: 65-76. ISSN 0044-8486. https://doi.org/10.1016/j.aquaculture.2015.03.013.

Khan, S.H., 2018. Recent advances in role of insects as alternative protein source in poultry nutrition. Journal of Applied Animal Research 46 (1): 1144-1157. https://doi.org/10.1080/09712119.2018.1474743.

Kolkovski, S., Czesny, S., Yackey, C., Moreau, R., Cihla, F., Mahan, D., Dabrowski, K., 2000. The effect of vitamin $C$ and $E$ in (n-3) highly unsaturated fatty acids-enriched 
Artemia nauplii on growth, survival, and stress resistance of freshwater walleye Stizostedion vitreum larvae. Aquaculture nutrition 6: 199-206. https://doi.org/10.1046/j.1365-2095.2000.00112.x.

Kumari, J., Sahoo, P.K., 2005 High dietary vitamin C affects growth, non-specific immune responses, and disease resistance in Asian catfish, Clarias batrachus. Molecular and Cellular Biochemistry 280: 25-33. https://doi.org/10.1007/s11010-005-8011-z.

Labh, S., 2017. Effects of feeding higher level of vitamin C Lascorbate-2-triphosphate Calcium (Latp) on growth and haemato-biochemical indices of common carp (Cyprinus carpio l). World Journal of Pharmaceutical Research 6: 904-921. https://doi.org/10.20959/wjpr20176-8529.

Li, Y., Lovell, R.T., 1985. Elevated Levels of Dietary Ascorbic Acid Increase Immune Responses in Channel Catfish. The Journal of Nutrition 115(1): 123-131. https://doi.org/10.1093/jn/115.1.123.

Little, D., Bhujel, R., Pham, T., 2003. Advanced nursing of mixed-sex and mono-sex tilapia (Oreochromis niloticus) fry, and its impact on subsequent growth in fertilized ponds. Aquaculture 221: 265-276. http://dx.doi.org/10.1016/S0044-8486(03)00008-5.

MacNiven, A. M., Little, D., 2001. Development and evaluation of a stress challenge testing methodology for assessment of Nile tilapia (Oreochromis niloticus) fry quality. Aquaculture research 32: 671-679. https://doi.org/10.1046/j.1365-2109.2001.00574.x.

Martins, M., Tavares-Dias, M., Fujimoto, R., Onaka, E., Nomura, D., 2004. Haematological alterations of Leporinus macrocephalus (Osteichtyes: Anostomidae) naturally infected by Goezia leporini (Nematoda: Anisakidae) in fishpond. Brazilian Journal of Veterinary and Animal Science 56: 640-646. https://doi.org/10.1590/S010209352004000500011.

Martins, T.P.A., Gomides, P.F.V., Navarro, F.K.S.P., Navarro, R.D., 2016. Vitamin C supplementation on growth performance and gonadal development in Nile tilapia. Technology Maringá 38(4): 477-481. https://doi.org/10.4025/actascitechnol.v38i4.28788. Naggar, G. O., Lovell, R. T., 1991. L-ascorbyl-2-monophosphate has equal antiscorbutic activity as L-ascorbic acid, but L-ascorbyl-2-sulfate is inferior to L-ascorbic acid for channel catfish. The Journal of nutrition 121(10): 1622-1626. https://doi.org/10.1093/jn/121.10.1622.

Ng, W.K., Chong C.Y., 2004. An overview of lipid nutrition with emphasis on alternative lipid sources in tilapia feeds. In R.G. Bolivar, G.C. Mair \& K. Fitzsimmons eds. Proceedings of the Sixth International Symposium on Tilapia in Aquaculture, 241-248pp. Bureau of Fisheries \& Aquatic Resources, Manila, Philippines.

NRC, National Research Council. 1993. Nutrient Requirements of Fish. Washington, DC: The National Academies Press. https://doi.org/10.17226/2115.

Nsonga, A.R., Kang'Ombe, J., W, Mfitilodze, W., Soko, C.K., Mtethiwa, A.H., 2010. Effect of varying levels of dietary vitamin C (ascorbic acid) on growth, survival, and hematology of juvenile tilapia, Oreochromis karongae (Trewavas 1941) reared in aquaria. Brazilian Journal of Aquatic Science and Technology 13: 17-23. https://doi.org/10.14210/bjast.v13n2.p17-23.

Ron, B., Shimoda, K. S., Iwama, G. K., Grau, E. G., 1995. Relationships among ration, salinity, 17a-methyltestosterone and growth in the euryhaline tilapia, Oreochromis mossambicus. Aquaculture 135:185-193. https://doi.org/10.1016/0044-8486(95)010130 .

Saha, D., Arisman, N., Mona, S., Yoshimatsu, T., 2010. Effects of different levels of vitamin $\mathrm{C}$ and prolonged nursing on growth and innate immunity of Nile tilapia, Oreochromis niloticus. AACL Bioflux., 10: 710-720.

Santiago C. B., Lovell R.T., 1988. Amino acid requirements for growth of Nile tilapia. Journal of Nutrition, 118(12): 1540-1546. https://doi.org/10.1093/jn/118.12.1540.

Sayed, A.E., Moneeb, R., 2015. Hematological and biochemical characters of mono-sex tilapia (Oreochromis niloticus, Linnaeus, 1758) cultivated using methyltestosterone. The Journal of Basic \& Applied Zoology 72: 36-42. https://doi.org/10.1016/j.jobaz.2015.03.002. 
Shahkar, E., Yun, H., Kim, D-J., Kim, S-K., Lee, B.I., Bai, S.C., 2015. Effects of dietary vitamin $C$ levels on tissue ascorbic acid concentration, hematology, non-specific immune response and gonad histology in brood-stock Japanese eel, Anguilla japonica. Aquaculture 438: 115-121. https://doi.org/10.1016/j.aquaculture.2015.01.001.

Soliman, K., Jauncey, K., Roberts, R.J., 1987. Stability of L-ascorbic acid (vitamin C) and its forms in fish feeds during processing, storage, and leaching. Aquaculture 60 (1): 73-83. https://doi.org/10.1016/0044-8486(87)90358-9.

Surachetpong, W., Roy, S.R.K., Nicholson, P., 2020. Tilapia lake virus: The story so far. Journal of Fish Disease 43(10): 1115-1132. https://doi.org/10.1111/jfd.13237.

Suseno, D.N., Luqman, E.M., Lamid, M., Mukti, A. Suprayudi, M.A., 2020. Residual impact of 17a-methyltestosterone and histopathological changes in sex- reversed Nile tilapia (Oreochromis niloticus). Asian Pacific Journal of Reproduction 9(1): 37-43. https://doi.org/10.4103/2305-0500.275527.

Suwanmanee, P., Nontawith, A., Prapansak, S., Taparhaudee, W., 2012. Effect of vitamin $C$ on growth and disease resistance of Nile tilapia larvae (Oreochromis niloticus Linn.). Proceeding of the 50th Kasetsart University Annual Conference. 418-427pp.

Taufek, N.M., Muin, H., Raji, A.A., Razak, S.A., 2016b. Apparent digestibility coefficients and amino acid availability of cricket meal, Gryllus bimaculatus, and fishmeal in African catfish, Clarias gariepinus, diet. Journal of the World Aquaculture Society 47 (6): 798-805. https://doi.org/10.1111/jwas.12302.

Taufek, N.M., Muin, H., Raji, A.A., Yusof, H.M., Alias, Z., Razak, S.A., 2017. Potential of Field cricket's meal (Gryllus bimaculatus) in the diet of African catfish. Journal of applied animal research 46(1): 541-546. https://doi.org/10.1080/09712119.2017.1357560.

Tewary, A., Patra, B., 2008. Use of vitamin C as an immunostimulant. Effect on growth, nutritional quality, and immune response of Labeo rohita (Ham.). Fish physiology and biochemistry 34 (3): 251-259. https://doi.org/10.1007/s10695-007-9184-z.

Toyama, G.N., Corrente, J.E., Cyrino, J.E.P., 2000. Vitamin C diet supplementation for sex reversal of the Nile tilapia. Sci. agric., 57(2): 221-228. https://doi.org/10.1590/S0103-90162000000200005.

Van Huis, A., 2013. Potential of insects as food and feed in assuring food security. Annual Review of Entomology 58: 563-583. https://doi.org/10.1146/annurev-ento-120811153704.

Vieira C.A.S.C., Vieira J.S., Bastos, M.S., 2018 Expression of genes related to antioxidant activity in Nile tilapia kept under salinity stress and fed diets containing different levels of vitamin C. Journal of Toxicol Environ Health 81: 20-30. https://doi.org/10.1080/15287394.2017.1401968.

Wang, X.J, Kim, K.W., Bai, S.C., Huh, M.D., Cho, B.Y., 2003. Effects of the different levels of dietary vitamin $\mathrm{C}$ on growth and tissue ascorbic acid changes in parrot fish, Oplegnathus fasciatus. Aquaculture 215: 203-211. https://doi.org/10.1016/S00448486(02)00042-X.

Wang, D., Zhai, S.W., Chuan-xi, Z., Bai, Y., An, S., Xu, Y., 2005. Evaluation on Nutritional Value of Field Crickets as a Poultry Feedstuff. Asian-Australian Journal of Animal science 18 (5): 667-670. https://dx.doi.org/10.5713/ajas.2005.667.

Yardimci, B., Aydin, Y., 2011. Pathological findings of experimental Aeromonas hydrophila infection in Nile tilapia (Oreochromis niloticus). Ankara Universitesi Veteriner Fakultesi Dergisi 58: 47-54. https://doi.org/10.1501/Vetfak 0000002448. 